\title{
Biodegradation of Lignocellulosic Wastes by Cultivation of Mushrooms as Nutrient Source
}

\author{
Vinit Singh Baghel \\ Government Nagarjuna Post Graduate College of Science, Raipur, Chhattisgarh, India
}

\begin{abstract}
India being an agriculture based country produces a large amount of lignocellulosic wastes which is either left to rot or is burned in the fields causing several environmental problems. Several mushrooms of high nutritional values are known to grow in these lignocellulosic wastes. Cultivation of such mushrooms using lignocellulosic wastes will not only solve the problem of lignocellulose biodegradation, but also act as a source of nutrition in the rural areas where malnutrition is prevalent.
\end{abstract}

Keywords: lignocellulose, mushroom cultivation, nutritional, lignocellulosic waste

\section{Introduction}

Lignocellulose is an organic matter which is renewable in nature and is structural component of all the plants, due to presence of lignin it becomes recalcitrant to bio-degradation. Different industries such as forestry, paper, agriculture, food and paper pulp produce a large amount of lignocellulosic waste each year [1]. These materials with high potential value for the production of many valuable substances are treated as waste in many developing countries and still are either left out to rot or incarnated causing serious environmental problems [2]. There have been many fungi identified which are known to degrade lignocellulosic waste, but all of them are not rendered fit to eat. Edible mushrooms are the fruiting bodies of the fungi, generally of the phylum Basidiomycota. The extracellular enzyme system of different rot fungi are capable of degrading the lignocellulosic material and use them as their substrate to grow and produce fruiting bodies. These mushrooms are known to have high nutritional value. In developing countries like India where 19.8 million children below the age of 6 years are undernourished (ICDS 2015) and only $9.6 \%$ children between 6 months to 2 years receive an adequate diet (NFHS 4, 2015-16), cultivating the large quantity of mushrooms on economic and readily available lignocellulosic substrates from agro industrial wastes can help the country in fighting against the malnutrition and also in safe biodegradation of the lignocellulosic waste. This review focuses on different types of edible mushrooms and the lignocellulosic wastes they can grow upon.

\section{History}

Mycophagy has been long practiced in human civilization The most primitive evidence found is 13,000 year old in Ötzi, the mummy which was buried with two species of edible mushrooms. The first mushroom found to be growing in the agricultural compost was Agricus bisporus, it was found growing in the melon compost. Earlier it was grown in open fields but later on its cultivation was moved to underground caves as it had more suitable atmospheric conditions. Mushroom cultivation in USA was introduced in 1865 , in $17^{\text {th }}$ century in Europe and in $19^{\text {th }}$ century in Netherlands. Japan and China are considered to be the first nations who exploited the medicinal uses of the mushrooms.
Shittake mushrooms (Lntinuela edodes) was grown only for medicinal purposes in China, as it helps in boosting immunity when administered along with AIDS drugs [3].

\section{Medicinal and Nutritional Properties of the Mushrooms}

Since a long times the mushrooms have been known to contain medicinally beneficial compounds and nutritious to health. L.edodes were grown in china just for their medicinal uses with the AIDS drugs [3]. P.ostreatus contains high values of carbohydrates, proteins, vitamins and minerals [4]. Many species of the mushrooms have been proven to be a great source of medicinally useful compounds to treat severe ailments such as, L.edodes is known to lower blood cholesterol levels and blood pressure, Tremella fuciformis spore extracts perform antilipemic activity, Grifola frondosa is known to lower blood pressure without changing plasma HDL levels and Trametes sp. is known for its antihyperlimic and antiarrhythmic effects [5]. The medicinal properties of some important culinary mushrooms are given in table 1 .

Table 1: Medicinal properties of some mushroom species

\begin{tabular}{|c|c|c|c|}
\hline $\begin{array}{l}\mathrm{Sr} \\
\text { no. }\end{array}$ & $\begin{array}{c}\text { Name of } \\
\text { species }\end{array}$ & Medicinal importance & Reference \\
\hline \multirow{5}{*}{01.} & \multirow{5}{*}{$\begin{array}{l}\text { Auricularia } \\
\text { polytrechia }\end{array}$} & Antioxidant activity & Mau et al. 2000 \\
\hline & & Immunomodulatory & Sheu et al. 2004 \\
\hline & & Antitumor & $\begin{array}{c}\text { Yu et al. 2004; Song } \\
\text { and Du } 2012\end{array}$ \\
\hline & & Anti-dementia activity & Bennet et. al 2013 \\
\hline & & $\begin{array}{c}\text { Attenuation of } \\
\text { inflammatory response } \\
\text { and oxidative stress }\end{array}$ & 2014 \\
\hline \multirow{4}{*}{02.} & \multirow{4}{*}{$\begin{array}{l}\text { Pleurotous } \\
\text { ostreatus }\end{array}$} & Extracts lower cholesterol & Khatun et al. 2007 \\
\hline & & Antinociceptive & Jayakumar et al. 200 \\
\hline & & Antitumor & Vasudewa et al. 2008 \\
\hline & & $\begin{array}{c}\text { Antioxidant and } \\
\text { immunological activities }\end{array}$ & Sarangi et al. 2006 \\
\hline 03. & $\begin{array}{l}\text { Pleurotous } \\
\text { florida }\end{array}$ & $\begin{array}{c}\text { Antioxidant and antitumor } \\
\text { properties }\end{array}$ & Josan J.K. 2000 \\
\hline
\end{tabular}

\section{Sources of lignocellulosic waste}

States and districts in India have access to a large no. of lignocellulosic wastes which are generated from farms, 


\section{International Journal of Science and Research (IJSR) \\ ISSN: 2319-7064}

ResearchGate Impact Factor (2018): 0.28 | SJIF (2019): 7.583

forests, processing industries and kitchen wastes. The major sources of lignocellulosic biomass are as below.

\subsection{Agricultural residue}

The agriculture is a major source of income for the rural livelihood and in the huge production of the crops large amount of agricultural residues are also generated. These residues can be classified into two types, primary and secondary. The residues that are left in the fields such as straw comes under primary residue and the products such as husk which are obtained after the processing of the crop are known as the secondary residue. All the agro lignocellulosic materials such produces have high biomass potential in range of $15000-1.5$ lakh (kilo tonnes/year) [6],[7].

\subsection{Industrial}

Lignocellulosic by-products from many industries such as paper, pulp, breweries etc. are released and causes various types of pollution. For example, the coffee production worldwide, for the production of per ton fresh coffee, produces 0.5 tons of coffee pulp and 0.18 ton husk per year [8], and also per year six million tons of spent coffee grounds are produced [9]. Caffeine present in the SCG is eco-toxic to a considerable limit and this presence of caffeine also presents hindrance to its many applications [10]. A range of filamentous fungi have been recorded to degrade the caffeine [11], but these have been only studied for the industrial degradation of caffeine containing wastes [12], [13].

\subsection{Food and kitchen wastes}

Left over foods, vegetables peels, fruit scrapes etc. usually remain untreated and left to rot in open causing many environmental and health problems.

\subsection{Forest waste}

Forests are found in abundance throughout the world at all times of the year irrespective of season and food habits of the people. Sawdust, leaves, logs, twigs, barks are among the lignocellulosic materials that can be obtained from the forests throughout the year.

\section{Composition of lignocellulosic residue}

Lignocellulose is an organic matter and acts as structural component of plants. Cellulose, hemicellulose and lignin are the prime constituent of the lignocellulosic materials. Cellulose and hemicellulose are sugar derivative macromolecules; whereas lignin are the aromatic polymers made from the phnylpropanoid precursors. The composition and ratio of these molecules may vary with different plants, [14]compiled a list of the same.(Table 2).
Table 2: Composition of various lignocellulosic materials (Carmen Sánchez 2009)

\begin{tabular}{|c|c|c|c|c|}
\hline Substrate & $\begin{array}{l}\text { Hemi- } \\
\text { cellulose }\end{array}$ & Lignin & Cellulose & References \\
\hline Hardwood stem & $24-40$ & $18-25$ & $40-45$ & $\begin{array}{c}\text { Howard et al. (2003), } \\
\text { malherbe and cloete } \\
(2002) .\end{array}$ \\
\hline \begin{tabular}{c|} 
Coastal \\
Bermuda grass \\
\end{tabular} & 35.7 & 6.4 & 25 & Howard et al. (2003) \\
\hline Sorted refuse & 20 & 20 & 60 & Howard et al. (2003) \\
\hline Corn cobs & 35 & 15 & 45 & $\begin{array}{l}\text { Howard et al. (2003), } \\
\text { prassad et al. (2007), } \\
\text { mckendry (2002). }\end{array}$ \\
\hline Grasses & $35-50$ & Oct-30 & $25-40$ & $\begin{array}{c}\text { Howard et al. (2003), } \\
\text { malherbe and cloete } \\
(2002) .\end{array}$ \\
\hline Paper & 0 & $0-15$ & $85-99$ & Howard et al. (2003) \\
\hline Rice straw & 24 & 18 & 32.1 & $\begin{array}{l}\text { Howard et al. (2003), } \\
\text { Prassad et al. (2007), } \\
\text { mckendry (2002). }\end{array}$ \\
\hline Nut shells & $25-30$ & $30-40$ & $25-30$ & Howard et al. (2003) \\
\hline Leaves & $80-85$ & 0 & $15-20$ & Howard et al. (2003) \\
\hline $\begin{array}{c}\text { Cotton seed } \\
\text { hairs }\end{array}$ & May-20 & 0 & $80-95$ & Howard et al. (2003) \\
\hline Newspaper & $25-40$ & 18-30 & $40-55$ & Howard et al. (2003) \\
\hline $\begin{array}{c}\text { Solid cattle } \\
\text { manure }\end{array}$ & $1.4-3.3$ & $2.7-5.7$ & $1.6-4.7$ & Howard et al. (2003) \\
\hline Softwood stem & $25-35$ & $25-30$ & $45-50$ & $\begin{array}{c}\text { Howard et al. (2003), } \\
\text { malherbe and cloete } \\
\text { (2002). }\end{array}$ \\
\hline Switch grass & 31.4 & 12 & 45 & Howard et al. (2003) \\
\hline $\begin{array}{c}\text { S32 rye grass } \\
\text { (early leaf) }\end{array}$ & 15.8 & 2.7 & 21.3 & Howard et al. (2003) \\
\hline Orchad grass & 40 & 4.7 & 32 & Howard et al. (2003) \\
\hline Wheat straw & $26-30$ & $16-21$ & $29-35$ & $\begin{array}{c}\text { Rowell (1992), } \\
\text { prassad et al. (2007), } \\
\text { mckendry (2002). }\end{array}$ \\
\hline Barley straw & $24-29$ & 14-15 & $31-34$ & Rowell (1992). \\
\hline Oat straw & $27-38$ & 16-19 & $31-37$ & Rowell (1992). \\
\hline Rye straw & $27-30$ & $16-19$ & $33-35$ & $\begin{array}{c}\text { Rowell (1992), } \\
\text { Stewart et al. (1997), } \\
\text { Hon (2000). } \\
\end{array}$ \\
\hline Bamboo & $15-26$ & $21-31$ & $26-43$ & $\begin{array}{l}\text { Rowell (1992), } \\
\text { reguant and rinaudo } \\
\text { (2000), hon (2000). }\end{array}$ \\
\hline Coffee pulp & 46.3 & 18.8 & 35 & $\begin{array}{l}\text { Pérez-díaz et al. } \\
(2005)\end{array}$ \\
\hline Banana waste & 14.8 & 14 & 13.2 & John et al. (2006). \\
\hline
\end{tabular}

\section{Bioconversion of lignocellulose}

Major components of the lignocellulosic materials are cellulose, hemicellulose and lignin with varying composition in different materials [15]. It is difficult to dissolve lignin without destroying its structure, hence it becomes tedious to ascertain its exact chemical structure. Normally lignin consists of three aromatic alcohols but the lignin found in dicots and grasses also contains phenolic acids esterified to alcohol groups. The lignin present in lignocellulose is also found to be attached with cellulose and hemicellulose covering them and creating a impermeable physical barrier.Due to these physical attributes it becomes recalcitrant to degradation [16]. Several chemical methods such as alkaline hydrolysis [17] and acid hydrolysis [18] have been proposed for the degradation of the lignocellulose, but, these methods produce undesirable 


\section{International Journal of Science and Research (IJSR) \\ ISSN: 2319-7064}

ResearchGate Impact Factor (2018): 0.28 | SJIF (2019): 7.583

byproducts and also the chemicals are hard to dispose hence the enzyme treatment is preferred over them. Further it has been shown that fungal extracellular enzymes such as cellulases are capable of converting lignocellulose into simpler compounds [19].

This lignocellulose degrading ability of the fungi can be attributed to their highly well-organized enzymatic system. There are two types of extracellular enzyme system, one which produces hydrolases for the degradation of polysaccharides and another one a unique extracellular and oxidative liginolytic system, which cleaves open phenyl rings and thus degrades lignin [20]. a schematic representation of lignin degradation by white rot fungi was given [21] (fig 1).

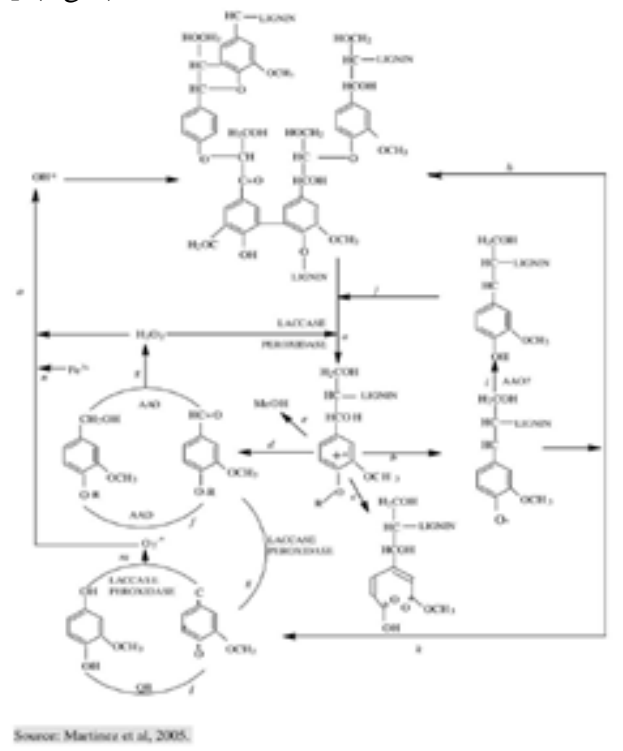

Figure 1: Schematic representation of lignin degradation by white rot fungi.

\section{Substrate preparation and supplements}

In the inceptive period of mushroom cultivation a solid fermentation process is involved. Before bearing the fruiting body the mycelium grows in an aseptic controlled medium from spawns to colonize the whole substrate [22]. Depending on the requirement of the different species of mushrooms two methods using agricultural by-products for the preparation of substrates have been employed.

1). Composted substrates prepared by fermentation and pasteurization [23],[24]. This type of substrate is useful in the cultivation of Agaricus bisporous, P. sajor-caju and Pleurotus ostreatus[25],[26],[27].

2). Non-composted substrates that are usually mixture of various agricultural by-products used as main components of the substrate system and stem sterilized before the inoculation of the spawns. The species best suited for this meathod are, Auricularia sp[28], Pleurotus eryngii [29], Flamnulina velvtipes[30], Agrocybe aegerita [31], volvariella volvacea[32] and Lentinuela edodes[27]. The $\mathrm{C}: \mathrm{N}$ ratio is unique for each mushroom variety and when the substrate is supplemented with this ratio in adequate amount the highest yield in a short span of time can be achieved [33]. Apart from the commercial supplements many agricultural by-products are being used as nutritional supplements. When substrates having high concentration of alperujo were used for the cultivation of Flammulina velutipes, it was observed that the phytotoxicity of this byproduct was reduced and the same time the mushroom showed good biological efficiency [34]. In Spain grapeseed meal, defatted pistachio and almond meal showed the same result for the cultivation of $A$. bisporous and P.ostreatus [35]. Several experiments as adding $25 \%$ of black bean, wheat bran and using soyabean, oat husk, and peanut shell with soya as supplement to $P$. ostreatus increased the protein of mushroom [36],[37]. Table 3 shows the various lignocellulosic materials used for different mushroom cultivation.

Table 3: Different cellulosic materials used for the mushroom cultivation

\begin{tabular}{|c|c|c|c|}
\hline $\begin{array}{l}\text { Sr. } \\
\text { no }\end{array}$ & Substrate composition & $\begin{array}{c}\text { Mushroom } \\
\text { variety }\end{array}$ & Reference \\
\hline 1 & $\begin{array}{c}\text { Barley straw + sugarbeet pulp } \\
+ \text { +rice bran }\end{array}$ & P.eryngii & $\begin{array}{l}\text { Zadrail F. et al. } \\
1992\end{array}$ \\
\hline 2 & vegetable + paddy straw & Pleurotus & Ralph et al. 1994 \\
\hline 3 & Soyabean straw + wheat straw & P. sajor-caju & Rani et al. 2008 \\
\hline 4 & $\begin{array}{c}\text { paddy straw }+ \text { neem cake+ } \\
\text { black and red gram husk }+ \\
\text { cotton seed cake }\end{array}$ & $\begin{array}{l}\text { Calocybe } \\
\text { indica }\end{array}$ & $\begin{array}{l}\text { Krishnmoorthy } \\
\quad \text { AS } 2003\end{array}$ \\
\hline 5 & Saw dust + rice husk & P.ostreatus & $\begin{array}{c}\text { Singh MP et al.. } \\
2012\end{array}$ \\
\hline 6 & Ramie stalks, Kenaf stalks & P.eryngii & $\begin{array}{c}\text { Chungliang et al. } \\
2016\end{array}$ \\
\hline 7 & $\begin{array}{c}\text { Rice straw, wheat straw, } \\
\text { cotton straw, tea leaves, } \\
\text { banana leaves }\end{array}$ & Pleurotus sp. & $\begin{array}{c}\text { Ritika k. et al. } \\
2017\end{array}$ \\
\hline 8 & wheat straw & $\begin{array}{l}\text { Agaricus } \\
\text { bisporous }\end{array}$ & $\begin{array}{c}\text { Ritika k. et al. } \\
2017 \\
\end{array}$ \\
\hline 9 & Rice bran, coffee pulp & $\begin{array}{l}\text { Lentinula } \\
\text { edodes }\end{array}$ & $\begin{array}{c}\text { Ritika k. et al. } \\
2017 \\
\end{array}$ \\
\hline 10 & Tea leaves & Volvallella & $\begin{array}{c}\text { Ritika k. et al. } \\
2017\end{array}$ \\
\hline 11 & saw dust & Ganoderma & $\begin{array}{c}\text { Ritika k. et al. } \\
2017\end{array}$ \\
\hline 12 & $\begin{array}{c}\text { composted sawdust }+ \\
\text { powdered Pineapple rind }\end{array}$ & P.ostreatus & $\begin{array}{c}\text { Deborah L.N.M et } \\
\text { al. } 2017 \\
\end{array}$ \\
\hline 13 & wheat straw + lathyrus straw & $\begin{array}{l}\text { Calocybe } \\
\text { indica }\end{array}$ & $\begin{array}{l}\text { Anurag k. et al. } \\
2018\end{array}$ \\
\hline 14 & Pennisetum purpureum & $\begin{array}{l}\text { Auricularia } \\
\text { polytricha }\end{array}$ & $\begin{array}{c}\text { Chih-Hung Liang } \\
\text { et al. } 2016\end{array}$ \\
\hline 15 & Perilla stalks & P.ostreatus & \begin{tabular}{|c|} 
Huizhen Li et al. \\
2017
\end{tabular} \\
\hline
\end{tabular}

All these lignocellulosic materials used as the substrate or supplement has shown to improve the yield, biological efficiencies and increase in the nutritional value of the various mushrooms.

\section{Other Experimental Substrates}

\subsection{Used coffee grounds}

There have been several efforts to reuse the waste products from production and consumption of coffee for the cultivation of mushrooms in different countries [38],[39]. It has been shown that using spent coffee grounds for mushroom cultivation has proved as an additional source of income for the coffee farmers of different countries [40],[41]. P.ostreatus is able to degrade about $86.6 \%$ of the

\section{Volume 9 Issue 5, May 2020 www.ijsr.net}




\section{International Journal of Science and Research (IJSR) \\ ISSN: 2319-7064}

ResearchGate Impact Factor (2018): 0.28 | SJIF (2019): 7.583

caffeine in the given substrate at particular concentration [42], making this process not only economically lucrative but also ecofriendly.

\subsection{Used tea leaves}

India holds prominent position among the top producers of the tea in the world. With great production comes the great drawback of unutilized waste that causes pollution when leaches in the ground. Tea leaves are also cellulosic material and hence readily can be used for the cultivation of mushrooms. Autoclaved tea leaveswere used waste along with wheat straw in different proportions for P.spadious and P.flabellates. 3:1 and 1:1 ratio of TLW:WS gave best yield for P.flabellates whereas 1:3 ratio gave best yield in P.spadious[43]. Tea leaves when used in the range of 40$60 \%$ along with cottonseed hulls gave best yield for P.oestrus [44]. P. sajor-caju gave better yield and fruiting body when sugarcane bagasse was added with tea leaves in ratio of 75:25\% and supplemented with 5\% lime [45].

\subsection{Banana leaves}

Banana cultivation is done throughout the country and a lot of agro waste is generated after each harvest. As it is rich in lignocellulosic content it can prove to be good substrate for the cultivation of Pleurotus mushrooms. V. volvacea grew well in the banana leaf substrate at the same time fugues treated substrate showed high cellulose content making it a viable as ruminant feed [46]. Among three substrates tested banana leaves showed highest production and biological efficiencies for two strains of $V$. volvacea V99 and VVO [47]. The leaf and pseudo-stem of banana showed promising results for the cultivation of P.ostreatus [48].

\section{Discussion}

India with about $70 \%$ of rural households engaged in agriculture has about 275 million tonnes of total food grain production which also contributes to ample amount of lignocellulosic waste production. This lignocellulosic waste is utilized in little amount to not being utilized at all. India has a temperate climatic condition, which makes it favorable for the cultivation of mushrooms. Several rot fungi such as Pleurotus are efficient in growing in lignocellulosic waste and producing protein rich mushrooms. These lignocellulosic wastes can be used along with the substrates for the cultivation of mushrooms as, this will not only produce protein rich food to fight malnutrition but also at the same time help us in biodegradation of lignocellulosic waste. Several substrates such as wheat straw, rice straw, lathyrus straw, spent coffee grounds, spent tea leaves, banana leaves, vegetables, soybean straw etc. have shown to be promising in the cultivation of mushrooms. In developing countries like India, malnutrition is a prevalent issue. This issue can only be addressed by adequate diet and protein rich supplements and mushroom along with lignocellulosic wastes as substrate can play a major role in it.

\section{Conclusion}

Agro wastes containing of lignocellulosic materials can prove as a great substrate and supplements for the production of mushrooms as these are cost effective and readily available. Cultivation of mushrooms on agro wastes and spreading awareness about them will help the rural farmers in uplifting their socio-economic conditions.

\section{References}

[1] Kim S, Dale BE: Global potential bioethanol production from wasted crops and crop residues. Biomass and Bioenergy 2004;26:361-375.

[2] Mehdi Dashtban, Heidi Schraft, Wensheng Qin, Fungal Bioconversion of Lignocellulosic Residues; Opportunities \& Perspectives Int. J. Biol. Sci. 2009, 5(6):578-595

[3] Ritika Kamthan and Ishita Tiwari(2017) Agricultural Wastes- Potential Substrates For Mushroom Cultivation. European Journal of Experimental Biology Vol.7 No.5:31

[4] Hilal, A., Dundar, A., Yildiz, A., 2012. Effect of using different lignocellulosic wastes for cultivation of Pleurotus ostreatus (Jacq.) P. Kumm. on mushroom yield, chemical composition and nutritional value. Afr. J. Biotechnol. 8 (4), 662-666.

[5] Solomon P. Wasser, Alexander L. Weis (1999) Medicinal Properties of Substances Occurring in Higher Basidiomycetes Mushrooms: Current Perspectives.International Journal of Medicinal Mushrooms, Vol 1, 47-50, (1999)

[6] Kumar A, Kumar N, Baredar P, Shukla A (2015) A review on biomass energy resources, potential, conversion and policy in India. Renewable and Sustainable Energy Reviews 45: 530-539.

[7] Murali S, Shrivastava R, Saxena M (2008) Quantification of agricultural residues for energy generation-a case study. J Inst Public Health Eng 3: 27.

[8] Roussos S, Aquiahuatl MD, Trejohernandez MD, Perraud IG, Favela E, Ramakrishna M, Raimbault M, Viniegragonzalez G (1995) Biotechnological management of coffee pulp - isolation, screening, characterization, selection of caffeine degrading fungi and natural microflora in coffee pulp and husk. Appl Microbiol Biotechnol 42: 756-762.

[9] Mussatto SI, Machado EMS, Martins S, Teixeira JA (2011) Production, composition, and application of coffee and its industrial residues. Food Bioprocess Technol 4:661-672.

[10] Janissen B, Huynh T (2018) Chemical composition and value-adding applications of coffee industry byproducts: a review. Resour Conserv Recycl 128:110 117.

[11] Dash SS, Gummadi SN (2006) Catabolic pathways and biotechnological applications of microbial caffeine degradation. Biotechnol Lett 28: 1993-2002.

[12] Brand D, Pandey A, Roussos S, Soccol CR (2000) Biological detoxification of coffee husk by filamentous fungi using a solid state fermentation system. Enzym Microb Technol 27:127-133.

[13] Hakil M, Voisinet F, Viniegra-Gonzalez G, Augur C (1999) Caffeine degradation in solid state fermentation by Aspergillus tamarii: effects of additional nitrogen sources. Process Biochem 35:103-109. 


\section{International Journal of Science and Research (IJSR) \\ ISSN: 2319-7064}

ResearchGate Impact Factor (2018): 0.28 | SJIF (2019): 7.583

[14] Sánchez C (2009) Lignocellulosic residues: biodegradation and bioconversion by fungi. Biotechnol Adv 27:185-194.

[15] Sun, Y. and Cheng, J. (2002). Hydrolysis of lignocellulosic material from ethanol production: A review. Biores. Technol. 83: 1-11

[16] C. Pothiraj, P. Kanmani and P. Balaji (2006) Bioconversion of Lignocellulose Materials Mycobiology 34(4): 159-165 (2006)

[17] Chahal, D. S. (1992). Bioconversions of polysaccharides of lignocellulose and simultaneous degradation of lignin. Pp 83-93. In: Kennedy et al. Eds. Lignocellulosics: Science, Technology,Development and Use. Ellis Horwood Limited, England.

[18] Nguyen, Q. A. (1993). Economic analyses of integrating a biomass- to-ethanol plant into a pulp/saw mill. Pp 321-340. In: Saddler. Eds. Bioconversion of Forest and Agricultural Plant. CAB International, UK.

[19] Luci Okino, Katia Machado, C.Fabris,Vera L. Ramos Bononi (2000) Ligninolytic activity of tropical rainforest basidiomycetes. World journal of microbiology and biotechnology. 16(8-9)

[20] Carmen Sánchez (2009), Lignocellulosic residues: Biodegradation and bioconversion by fungi Biotechnology Advances 27 (2009) 185-194

[21] Martínez AT, Speranza M, Ruiz-Dueñas FJ, Ferreira P, Camarero S, Guillén F, et al.(2005) Biodegradation of lignocellulosics: microbial, chemical, and enzymatic aspects of the fungal attack of lignin. Int Microbiol 2005;8:195-204.

[22] Zervakis GI, Koutrotsios G (2017) Solid-state fermentation of plant residues and agro-industrial wastes for the production of medicinal mushrooms. In: Agrawal D, Tsay HS, Shyur LF, Wu YC, Wang SY (eds) Medicinal plants and fungi: recent advances in research and development. Medicinal and aromatic plants of the world, vol 4. Springer, Singapore, pp 365-396.

[23] Kabel MA, Jurak E, Mäkelä MR, de Vries RP (2017) Occurrence and function of enzymes for lignocellulose degradation in commercial Agaricus bisporus cultivation. Appl Microbiol Biot 101:4363-4369.

[24] Vos AM, Jurak E, Pelkmans JF, Herman K, Pels G, Baars JJ, Hendriz E, Kabel MA, Lugones LG, Wösten HA (2017) $\mathrm{H} 2 \mathrm{O} 2$ as a candidate bottleneck for MnP activity during cultivation of Agaricus bisporus in compost. AMB Expr 7:124.

[25] Pardo-Giménez A, Pardo JE, Zied DC (2017b) Supplementation of high nitrogen Agaricus compost: yield and mushroom quality. J Agr Sci Tech 19:15891601

[26] Sánchez C (2010) Cultivation of Pleurotus ostreatus and other edible mushrooms. Appl Microbiol Biotechnol 85:1321-1337

[27] Chang S, Miles PG (2004) Mushrooms: cultivation, nutritional value, medicinal effect and environmental impact, 2nd edn. CRC Press, Boca Raton. ISBN 08493-1043-1

[28] Estrada AER, Jimenez-Gasco MM, Royse DJ (2009) Improvement of yield of Pleurotus eryngii var. eryngii by substrate supplementation and use of a casing overlay. Bioresour Technol 100:5270-5276.
[29] Xie C, Gong W, Yan L, Zhu Z, Hu Z, Peng Y (2017) Biodegradation of ramie stalk by Flammulina velutipes: mushroom production and substrate utilization. AMB Expr 7:171.

[30] Liang CH, Wu CY, Lu PL, Kuo YC, Liang ZC (2016) Biological efficiency and nutritional value of the culinary-medicinal mushroom Auricularia cultivated on a sawdust basal substrate supplement with different proportions of grass plants. Saudi J Biol Sci.http://dx.doi.org/10.1016/j.sjbs.2016.10.017

[31] Kleofas V, Sommer L, Fraatz MA, Zorn H, Rühl M (2014) Fruiting body production and aroma profile analysis of Agrocybe aegerita cultivated on different substrates. Nat Res 5:233-240.

[32] Yamanaka K (2017) Cultivation of mushroom in plastic bottles and small bags. In: Zied DC, PardoGiménez A (eds) Edible and medicinal mushrooms: technology and applications. Wiley, Hoboken, pp 385 413.

[33] Zied DC, Cardoso C, Pardo-Giménez A, Dias E, Zeraik ML, Pardo JE (2018) Using of appropriated strains in the practice of compost supplementation for Agaricus subrufescens production. Front Sustain Food Syst.

[34] Rugolo M, Levin L, Lechner BE (2016) Flammulina velutipes: an option for "alperujo" use. Rev Iberoam Micol 33(4):242-247

[35] Pardo-Giménez A, Catalán L, Carrasco J, Álvarez-Ortí M, Zied D, Pardo J (2016) Effect of supplementing crop substrate with defatted pistachio meal on Agaricus bisporus and Pleurotus ostreatus production. J Sci Food Agric 96(11):3838-3845.

[36] Colmenares-Cruz S, Sánchez JE, Valle-Mora J (2017) Agaricus bisporus production on substrates pasteurized by self-heating. AMB Express 7(1):135.

[37] Jeyanthi Rebecca L, Seshiah C, Kowsalya E, Sharmila S (2015) Effect of food processing waste on the growth and nutrition quality of Pleurotus ostreatus. Int $\mathrm{J}$ Pharm Technol 7(2):8887-8893

[38] Salmones D, Mata G, Waliszewski KN (2005) Comparative culturing of Pleurotus spp. on coffee pulp and wheat straw: biomass production and substrate biodegradation. Bioresour Technol 96:537-544

[39] Fan L, Pandey A, Mohan R, Soccol CR (2000) Use of various coffee industry residues for the cultivation of Pleurotus ostreatus in solid state fermentation. Acta Biotechnol 20:41-52.

[40] Jaramillo C, Rodríguez N, Chang ST (2010) Simple methodology for the cultivation of the medicinal mushroom Ganoderma lucidum in Colombian coffee farms. In: Martinez-Carrera D, Curvetto N, Sobal M, Morales P, Mora VM (eds) Hacia un desarrollo sostenible del sistema de producción-consumo de los hongos comestibles y medicinales en Llatinoamérica: avances y perspectivas en el Siglo XXI Red Latinoamericana de Hongos Comestibles y Medicinales, Puebla, Mexico, pp 397-405

[41] Martínez-Carrera D, Aguilar A,MartínezW, BonillaM, Morales P, Sobal M (2000) Commercial production and marketing of edible mushrooms cultivated on coffee pulp in Mexico. In: Sera T, Soccol CR,

[42] Claudia P. Carrasco-Cabrera \& Tina L. Bell \& Michael A. Kertesz (2019) .Caffeine metabolism during 


\section{International Journal of Science and Research (IJSR) \\ ISSN: 2319-7064}

ResearchGate Impact Factor (2018): 0.28 | SJIF (2019): 7.583

cultivation of oyster mushroom (Pleurotus ostreatus) with spent coffee grounds Applied Microbiology and Biotechnology (2019) 103:5831-5841

[43] Ramesh C. Upadhyay, Bhuvnesh Vijay and Rabindra Nath Verma(1996) use of industrial tea leaves waste for the cultivation of oyster mushrooms. Mushroom biology and mushroom products, Royse(ed.) 1996 Penn state univ. ISBN 1-883956-01-3.

[44] Doudou Yang, Jin Liang, YunshengWang, Feng Sun, Hong Tao, Qiang Xu, Liang Zhang, Zhengzhu Zhang, Chi-Tang Ho and XiaochunWan (2015)Tea waste: an effective and economic substrate for oyster mushroom cultivationJournal of the Science of Food and Agriculture 2015 (wileyonlinelibrary.com) DOI $10.1002 /$ jsfa. 7140

[45] Nalini Devi Chukowry, Rita Devi Nowbuth, Bhanooduth Lalljee. Evaluation of Tea Wastes as an Alternative Substrate for Oyster Mushroom Cultivation. University of mauritius research journal volume $15-2009$

[46] Belewu, M. A. and Belewu, K.Y. Cultivation of mushroom (Volvariella volvacea) on banana leaves. African journal of biotechnology Vol. 4 (12), pp. 1401 1403

[47] M Obodai, J Cleland-Okine and P-NT Johnson (2003). Use of agricultural wastes as substrate for the mushroom Volvariella volvacea Trop. Sci. 2003, 43, 121-124

[48] Cristiane Suely Melo de Carvalho1, Lorena Vieira Bentolila de Aguiar, Ceci Sales-Campos, Marli Teixeira de Almeida Minhoni, Meire Cristina Nogueira de Andrade 2012. Applicability of the use of waste from different banana cultivars for the cultivation of the oyster mushroom. Brazilian journal of microbiology (2012): 819-826

[49] Aurag K, NK pandey, Hk Singh and CS Shukla(2018) Effect of straw subtrates and casing materials on the yield of milky mushroom (Calocybe indica P\&C) Strain CI524. Int.J.Microbiol.App.Sci(2018) 7(2): 317322

[50] Bennett, L., Sheean, P., Zabaras, D., Head, R., 2013. Heat-stable components of wood ear mushroom, Auricularia polytricha (higher Basidiomycetes), inhibit in vitro activity of beta secretase (BACE1). Int. J. Med. Mushr. 15, 233-249.

[51] Chiu, W.C., Yang, H.H., Chiang, S.C., Chou, Y.X., Yang, H.T., 2014. Auricularia polytricha aqueous extract supplementation decreases hepatic lipid accumulation and improves antioxidative status in animal model of nonalcoholic fatty liver. Biomedicine 4, 29-38.

[52] Chunliang Xie, Li Yan, Wenbing Gong, Zuohua Zhu, Senwei Tan, Du Chen, Zhenxiu $\mathrm{Hu}$, Yuande Peng(2016) Effects of Different Substrates on Lignocellulosic Enzyme Expression, Enzyme Activity, Substrate Utilization and biological efficiency of Pleurotus eryngiiCell Physiol Biochem 2016;39:1479 1494

[53] Claudia P. Carrasco-Cabrera \& Tina L. Bell \& Michael A. Kertesz (2019) .Caffeine metabolism during cultivation of oyster mushroom (Pleurotus ostreatus) with spent coffee grounds Applied Microbiology and Biotechnology (2019) 103:5831-5841
[54] Hon DNS. Pragmatic approaches to utilization of natural polymers: Challenges and opportunities. In: Frollini E, Leao AL, Mattoso LHC, editors. Natural polymers and agrofibers composites. New York: Marcel Dekker Inc; 2000. p. 1-14

[55] Howard RL, Abotsi E, Jansen van Rensburg EL, Howard S (2003). Lignocellulose biotechnology: issues of bioconversion and enzyme production. Afr $\mathbf{J}$ Biotechnol 2003;2:602-19.

[56] Huizhen Li, Zhijun Zhang, Mengxue Li, Xiaojun Li, Ziwen Sun(2017) Yield, size, nutritional value, and antioxidant activity of oyster mushrooms grown on perilla stalks.Saudi Journal of Biological Sciences (2017) 24, 347-354

[57] Jayakumar, T., Thomas, P.A., Geraldine, P., 2009. Invitro antioxidant activities of an ethanolic extract of the oyster mushroom, Pleurotus ostreatus. Innovative Food Sci. Emerg. Technol. 10 (2), 228-234.

[58] Josen, J.K., 2000. Antioxidant and antitumour activity of Pleurotus florida. Curr. Sci. 79 (7), 941-943.

[59] Kabel MA, Jurak E, Mäkelä MR, de Vries RP (2017) Occurrence and function of enzymes for lignocellulose degradation in commercial Agaricus bisporus cultivation. Appl Microbiol Biot 101:4363-4369.

[60] Kamthan R, Tiwari I (2017) Agricultural WastesPotential Substrates For Mushroom Cultivation. Eur Exp Biol. Vol. 7 No. 5:31.

[61] Khatun, K., Mahtab, H., Sayeed, P.A., Sayeed, M.A., Khan, K.A., 2007. Oyster mushroom reduced blood glucose and cholesterol in diabetic subjects. Myrmecological News 16 (1), 94-99.

[62] Krishnamoorthy AS.(2003) Commercial prospects of milky mushroom (Cotocybe indica) on tropical plains of India. In: Upadhyay RC, Singh SK and Rai RD, editors. Current vistas in mushroom biology and production. Solan (HP): Mushroom Society of India; 2003. p. 131-5.

[63] Malherbe S, Cloete TE (2002). Lignocellulose biodegradation: fundamentals and applications. Reviews Environ Sci Bio/Technol 2002;1:105-14.

[64] Martínez AT, Speranza M, Ruiz-Dueñas FJ, Ferreira P, Camarero S, Guillén F, et al.(2005) Biodegradation of lignocellulosics: microbial, chemical, and enzymatic aspects of the fungal attack of lignin. Int Microbiol 2005;8:195-204.

[65] Mau, J.L., Chao, G.R., Wu, K.T., 2001. Antioxidant properties of methanolic extracts from several ear mushrooms. J. Agric. Food Chem. 49, 5461-5467.

[66] McKendry P(2002). Energy production from biomass: overview of biomass. Bioresour Technol 2002;83:3743.

[67] Pardo-Giménez A, Pardo JE, Carrasco J, Álvarez-Ortí M, Zied DC (2014) Use of Phase II mushroom compost in Agaricus subrufescens production. In: Proceedings of 8th International Conference on Mushroom Biology and Mushroom Products (ICMBMP8). ICAR-Directorate of Mushroom Research, Solan, India. pp 516-522

[68] Pérez J, Muñoz-Dorado J, De-la-Rubia T, Martínez J (2002). Biodegradation and biological treatments of cellulose, hemicellulose and lignin: an overview. Int Microbiol 2002;5:53-63. 


\section{International Journal of Science and Research (IJSR) \\ ISSN: 2319-7064}

ResearchGate Impact Factor (2018): 0.28 | SJIF (2019): 7.583

[69] Pérez-Díaz N, Márquez-Montesinos F, Autíe PM. Obtención del carbón activado a partir del residual sólido generado en el beneficio húmedo del café. Pinar del Río: CIGET;2005 (www.ciget.pinar.cu/No.20052/beneficio.htm)

[70] Poonam D et al (2013). Effect of different agro-waste substrates and their combinations on the yield and biological efficiency of Pleurotus sajor- caju. IOSR Journal of Pharmacy and Biological Sciences (IOSRJPBS Volume 8, Issue 3 (Nov. - Dec. 2013), PP 60-64

[71] Prassad S, Singh A, Joshi HC (2007). Ethanol as an alternative fuel from agricultural, industrial and urban residues. Resour Conserv Recycl 2007;50:1-39.

[72] Ralph H, Kurtzman J (1994) Nutritional needs of mushroom and substrate supplements. In: Nair MC (editor), Advances in mushroom biotechnology: 106110.

[73] Rani P, Kalyani N, Prathiba K (2008) Evaluation of Lignocellulosic Wastes for Production of Edible Mushrooms. Applied Biochemistry And Biotechnology 151: 151-159.

[74] Reguant J, Rinaudo M. Fibres Lignocellulosiques. En Iniciation á la Chimie et á (2000) la Physico-Chimie Macromoleculares. Les polymères naturels: Structure, modifications, applications. Groupe Français d'études et d'applications des polymères, France; 2000. p. 13.

[75] Rowell MR.( 1992) Opportunities for lignocellulosic materials and composites. Emerging technologies for material and chemicals from biomass: Proceedings of symposium. Washington, DC: American Chemical Society; 1992. p. 26-31. Chap.2.

[76] Sarangi, I., Ghosh, D., Bhutia, S.K., Mallick, S.K., Maiti, T.K., 2006. Anti-tumor and immunomodulating effects of Pleurotus ostreatus mycelia-derived proteoglycans. Int. Immunopharmacol. 6 (8), 12871297.

[77] Sheu, F., Chien, P.J., Chien, A.L., Chen, Y.F., Chin, K.L., 2004. Isolation and characterization of an immunomodulatory protein (APP) from the Jew's Ear mushroom Auricularia polytricha. Food Chem. 87, 593-600.

[78] Singh MP, Singh VK (2012) Biodegradation of Vegetable and Agro Wastes by Pleurotus Sapidus: A Novel Strategy to Produce Mushroom with Enhanced Yield and Nutrition. Cell Mol Biology (Noisy-LeGrand) 58: 1-7.

[79] Stewart D, Azzini A, Hall A, Morrison I(1997). Sisal fibers and their constituent non-cellulosic polymers. Ind Crops Prod 1997;6:17-26.

[80] Taylor JW, Ellison CE (2010) Mushrooms: morphological complexity in the fungi. PNAS 107(26):11655-11656.

[81] Vasudewa, N.S., Abeytunga, D., Ratnasooriya, W.D., 2008. Activity directed fractionation of Pleurotus ostreatus in search of analgesics. Pharm. Biol. 46 (5), 295-301.

[82] Vos AM, Jurak E, Pelkmans JF, Herman K, Pels G, Baars JJ, Hendriz E, Kabel MA, Lugones LG, Wösten HA (2017) $\mathrm{H} 2 \mathrm{O} 2$ as a candidate bottleneck for MnP activity during cultivation of Agaricus bisporus in compost. AMB Expr 7:124.
[83] Zadrail F, Dube HC (1992) The Oyster MushroomImportance and Prospects. Mushroom Resource 1: 2532.

[84] Zervakis GI, Koutrotsios G (2017) Solid-state fermentation of plant residues and agro-industrial wastes for the production of medicinal mushrooms. In: Agrawal D, Tsay HS, Shyur LF, Wu YC, Wang SY (eds) Medicinal plants and fungi: recent advances in research and development. Medicinal and aromatic plants of the world, vol 4. Springer, Singapore, pp 365-396.

\section{Author Profile}

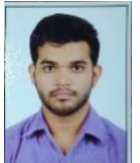

Vinit Singhwill complete his bachelor's in biotechnology in 2020 from govt. Nagarjuna PG College of science. Author has published papers in national and international journals.

Volume 9 Issue 5, May 2020 www.ijsr.net 